\title{
DA SECULARIZAÇÃO À PROFANAÇÃO, DA ESCATOLOGIA AO MESSIANISMO: GIORGIO AGAMBEN E AS ASSINATURAS TEOLÓGICAS DO PODER MODERNO ${ }^{1}$
}

\author{
Caetano Sordi ${ }^{2}$
}

Resumo: Este artigo discute os conceitos de secularização e profanação, escatologia e messianismo, a partir da obra recente do filósofo italiano Giorgio Agamben, sobretudo os livros O Reino e a Glória (2007) e Profanaçôes (2005). No primeiro livro, o autor opera uma genealogia conceitual que busca iluminar as assinaturas teológicas sob os conceitos de "governo" e "economia" na tradição ocidental, de modo a reconstituir sua progressiva secularização. Nesse sentido, Agamben pode ser considerado um continuador da teologia política de Carl Schmitt (1888-1985), para a qual todos os conceitos políticos modernos seriam conceitos teológicos secularizados. No entanto, ainda que o autor concorde com Schmitt quanto ao fato de que a política moderna possui certas "assinaturas" teológicas, o conteúdo propriamente político ou normativo da sua agenda intelectual destoa da visão autoritária esboçada por Schmitt como consequência da teologia política, aproximando-se, a bem da verdade, de um neomessianismo anárquico e radical. Este neomessianismo, argumenta o artigo, é representado pelo conceito de profanação, que aparece na obra de Agamben como a antítese estrutural da secularização.

Palavras-chave: Giorgio Agamben; Teologia política; Secularização; Poder moderno.

Abstract: The article discusses the concepts of secularization and profanation, eschatology and messianism, in the work of Italian philosopher Giorgio Agamben,

1 Este artigo é fruto da minha monografia de conclusão de curso, denominada "Da Secularização à Profanação: uma discussão a partir da genealogia teológica dos conceitos de governo e economia em Giorgio Agamben", defendida em 2012 no curso de Filosofia da Pontifícia Universidade Católica do Rio Grande do Sul, sob a orientação do Prof. Agemir Bavaresco. Agradeço ao professor orientador, bem como aos professores Norman R. Madarasz e Nythamar F. de Oliveira pela apreciação do trabalho e por suas sugestōes.

2 Filósofo (PUCRS), mestre e doutorando em Antropologia Social (PPGAS/UFRGS). E-mail: caetano.sordi@gmail.com

Debates do NER, Porto Alegre, ANo I4, N. 24, P. I4I-I64, JUl./DeZ. 2013 
especially the books Il regno e la gloria (2007) and Profanazioni (2005). In the first of these, the author works with a conceptual genealogy that seeks to illuminate the theological signatures under the concepts of "government" and "economy" in the western tradition, in order to reconstitute its progressive secularization. In this sense, Agamben can be considered a follower of Carl Schmitt's (18881985) political theology, for which all modern political concepts were secularized theological concepts. However, even if the author agrees with Schmitt that modern politics has some theological "signatures", the political and normative content of his intellectual agenda clashes with Schmitt's authoritarian view, rather approaching a radical and anarchical neo-messianism. The article argues that this neo-messianism is represented by the concept of profanation, which appears in Agamben's work as the structural antithesis of secularization.

Keywords: Giorgio Agamben; Political theology; Secularization; Modern power.

De acordo com uma tradição filosófica atualmente representada por pensadores como Jürgen Habermas, o decurso histórico da Modernidade coincide com o decurso histórico daquilo que se convencionou chamar de secularização. Giorgio Agamben (2011) registra que este conceito desempenhou um papel estratégico na cultura moderna, sobretudo após a obra de Max Weber, através da qual ele passou a significar o enfraquecimento do religioso nas sociedades ocidentais sob a forma de "desencantamento do mundo" [Entzäuberung der Welt]. Na mesma linha, Simon Critchley (2012) argumenta que a secularização é comumente compreendida como a separação moderna entre política e teologia, espaço público e espaço privado, Estado e religião, preconizada pelo Iluminismo em sua defesa do Estado laico e da liberdade religiosa.

$\mathrm{Na}$ medida em que a política e o Estado modernos se erigem a partir de uma exclusão das justificações teológicas da soberania, o poder e seu exercício tiveram de encontrar alhures, isto é, para além da divindade e sua transcendência $a$-histórica, seu manancial de legitimação. Assim, rupturas e eventos críticos na ordem histórica - como guerras, revoluções e insurgências populares - passaram a concentrar no imaginário moderno o ideário da fundação da ordem política e da violência legitimada: serão a Independência Norte-Americana (1779) e a Revolução Francesa (1789), eventos fulcrais da 
Modernidade política, que oferecerão os protótipos mais bem acabados destas supostas "criações ex nihilo" da nova ordem secular (Catroga, 2006). Igualmente, ficções normativas como o "contrato social" passaram a representar, no campo das ideias, o eidos da originalidade imanente das instituições políticas e sociais. Cumprindo a mesma via de "autonomização" das demais esferas da vida social preconizada por Max Weber, o pensamento filosófico e científico sobre a política na Modernidade também se afastará cada vez mais da religião e da teologia, fundando seu próprio programa de pesquisa e investigação.

Uma tradição paralela de investigações, contudo, desenvolveu-se na Alemanha da primeira metade do século XX e permaneceu adormecida até que os contemporâneos conflitos envolvendo religião e política em escala global viessem a acordá-la novamente. Parafraseando Fernando Catroga, trata-se de uma tradição pautada pela secularização como

[...] uma transferência do conteúdo, dos esquemas e dos modelos elaborados no campo religioso, para o campo profano, o que acaba por relativizar a novidade radical dos tempos modernos, assim reduzidos à condição de herdeiros, não obstante todas as suas ilusões de autofundação (Catroga, 2006, p. 17).

O principal nome vinculado a essa tradição é o jurista Carl Schmitt (1888-1985), muitas vezes lembrado como um "pensador maldito" por sua adesão ao nacional-socialismo e por seu ceticismo em relação à democracia liberal. Em sua Teologia Politica (1922 [2009]), Schmitt formula a famosa expressão segundo a qual todos os conceitos relevantes da moderna doutrina do Estado [Staatslehre] seriam conceitos teológicos secularizados. Em suas pesquisas, o jurista segue à risca este preceito, interessando-se particularmente pelas questôes referentes ao conceito moderno de soberania e suas possíveis raízes teológicas. Esta soberania pode ser compreendida como o "sujeito" do poder, isto é, quem, afinal de contas, se revela como detentor dele quando a normalidade jurídica é rompida. O conceito de soberania de Schmitt, portanto, vincula-se à capacidade de decidir pela instauração do estado de exceção [Ausnahmezustand], conceito através do qual é muitas vezes identificado na filosofia política. 
Como bem observa Critchley (2012), a ênfase dada por Schmitt à questão da soberania através do conceito de estado de exceção aponta duplamente para (1) sua crítica à democracia liberal (representada, à época, pela frágil República de Weimar) e (2) sua crença na fundamentação teológica dos conceitos políticos contemporâneos. De acordo com este comentarista,

[...] o problema de Schmitt com o liberalismo é que ele é antipolítico. O que significa que, para o liberal, toda decisão política deve ser baseada em uma norma, cuja última justificação provém da constituição. No liberalismo, as decisões políticas são derivadas de normas constitucionais e acima do Estado encontra-se a lei e sua interpretação. É por isso que no Estado liberal a mais alta autoridade política reside na Suprema Corte ou seu equivalente. A atividade política é subordinada à interpretação jurídica. [...] O triunfo do liberalismo, como o triunfo do teísmo, é a hegemonia de uma visão religiosa do mundo que procura banir o milagre, assim como aquilo que rompe com a situação legal-constitucional (Critchley, 2012, p. 104-105).

Em última análise, a figura que resplandeceria na ordem liberal seria a do mundo como o grande relógio newtoniano, abandonado por Deus em sua magnífica perfeição eterna. Em outras palavras, o mais puro deísmo. $\mathrm{O}$ que Schmitt rejeita nesta visão de mundo é a sua anulação do voluntarismo em favor da norma, neutralizando, em certa medida, a capacidade de ação do soberano. Cumpre identificar aqui a afinidade estabelecida entre a emergência desta visão de mundo, que tem seu paradigma na física newtoniana (ponto de partida das ciências naturais modernas) e o processo moderno de secularização e autonomização da vida política, agora rotinizada e desencantada através do "naturalismo político" das rotinas burocráticas e administrativas.

György Géreby (2008) relembra que Erik Peterson (1890-1968) também faz parte dessa tradição. Em sua obra de 1926 denominada Heis Theos: epigraphische, formgeschichtliche und religionsgeschichtliche Untersuchungen, este teólogo descreve e analisa a história da aclamação "um Deus!" [heis theos] no cristianismo antigo, assim como a subjacente imbricação entre religião e política contida nela. Segundo a sua investigação, esta aclamação, herdada do judaísmo, seria o elemento oculto que uniria Deus a seu povo

Debates do NER, Porto Alegre, ANo I4, N. 24, P. I4I-I64, JUl./DEZ. 2013 
ao manifestar seu mútuo pertencimento e, com isso, daria vida à própria comunidade como ecclesia. Para Géreby (2008), o grande insight de Peterson teria sido a constatação de que a constituição da comunidade cristã era um fato eminentemente político, expressado e perenizado por um sem-número de litanias, doxologias, hinografias e liturgias. Já contidas na sua dissertação, as consequências políticas desta aclamação pública de um "Um" [heis] foram posteriormente desenvolvidas em trabalhos sobre o conceito de monarquia.

$\mathrm{Na}$ parcela da sua obra aqui enfocada, o italiano Giorgio Agamben se apropria dessa tradição, por assim dizer, "esquecida" da teologia política para dar continuidade ao grande projeto de genealogia do poder moderno como "governo de coisas e pessoas" estruturado por Michel Foucault (2008a; 2008b; 2011) nos anos 1970 e 1980, autor ao qual pretende se vincular. Sua releitura do conceito schmitteano de estado de exceção para compreender a articulação soberana entre auctoritas e potestas na política atual é bastante conhecida (Agamben, 2002; 2007c), representando, de fato, um marco na redescoberta da obra do jurista alemão e no contemporâneo interesse pela teologia política (Géreby, 2008; Negri, 2008; Critchley, 2012). O que pretendo discutir neste artigo, no entanto, é o sentido dado às ideias de secularização e profanação por Agamben em sua obra, partindo do livro O Reino e a Glória: uma genealogia teológica da economia e do governo, de 2007, e da coletânea de ensaios Profanaçôes, de 2005, ambos publicados no Brasil pela editora Boitempo ${ }^{3}$.

Meu argumento é que, embora o filósofo italiano concorde com Schmitt e Peterson quanto ao fato de que a política moderna possui o que chama de "assinaturas" teológicas, o conteúdo propriamente político ou normativo da sua agenda filosófica destoa completamente da visão conservadora e autoritária esboçada por Schmitt como consequência de sua teologia política, aproximando-se, a bem da verdade, de um neomessianismo. A marca deste neomessianismo seria o seu conceito de profanação, que se apresenta em seu discurso como o oposto estrutural da secularização. Como pretendo demonstrar, enquanto esta se desenvolve de acordo com uma escatologia (apontando

3 Neste artigo, utilizo como referência estas duas edições brasileiras (Agamben, 2011 e Agamben, 2007b, respectivamente).

Debates do NER, Porto Alegre, ANo I4, N. 24, P. I4I-I64, JUl./DeZ. 2013 
para o "final dos tempos", uma teleologia), aquela seria capaz de conduzir a ação política em direção ao messiânico, isto é, uma forma de vida que se dá desde a desativação de qualquer teleologia. $\mathrm{O}$ que se coloca em jogo aqui é a própria interpretação fornecida por Agamben sobre a governamentalidade moderna como fruto de uma secularização, assim como a possibilidade de sua desativação desde uma profanação.

\section{OS SENTIDOS DA SECULARIZAÇÃO}

O Reino e a Glória representa uma etapa importante do pensamento de Agamben. Seguindo a interpretação de Negri (2008), poderíamos classificar o livro como um intermezzo entre a antropologia filosófica esboçada em Homo Sacer (2002) e desenvolvida em Estado de Exceção (2007c) e um futuro quarto volume da série, dedicado, ao que tudo indica, "ao significado crucial da inatividade como aquilo que é próprio do humano e da práxis política” (Negri, 2008, p. 96). Ainda segundo Negri, o livro compóe-se de duas partes distintas: a primeira, referente ao "Reino", assinalaria a conclusão do projeto schmitteano de redução das categorias políticas modernas a dimensões da teologia política. A segunda parte, dedicada à "Glória", realizaria uma genealogia da ideia de consenso no Estado moderno, dimensão que Agamben interpreta, à maneira de Peterson, como a história das formas de sacralidade e aclamação.

$\mathrm{O}$ conceito metodológico central da genealogia esboçada em $O$ Reino e a Glória é o de "assinatura". Como salienta Edgardo Castro (2010), enquanto a genealogia de Foucault é marcada por um exame das "práticas", a de Agamben pontua-se por um desvelamento destas "assinaturas". Por elas, devemos compreender as marcas que, presentes num determinado conceito, remetem-no à sua matriz original, em outro contexto de significado. $\mathrm{O}$ rastreamento destas marcas, de acordo com Agamben, conduz-nos desde a superfície do conceito até o lugar em que esta marca, agora exposta, torna o próprio conceito inteligível. Nas palavras do próprio autor, "as assinaturas transferem e deslocam os conceitos e os signos de uma esfera para outra, neste caso, do sagrado para o profano, e vice-versa, sem redefini-los semanticamente" (Agamben, 2011, p. 16). Deste modo, uma assinatura seria algo que, em

Debates do NER, Porto Alegre, ANo I4, N. 24, P. I4I-I64, JUl./DEZ. 2013 
um signo ou conceito, "marca-os e excede-os para remetê-los a determinada interpretação ou determinado âmbito, sem sair, porém, do semiótico, para constituir um novo significado ou um novo conceito" (idem).

Para Agamben, o rastreamento dessas assinaturas logra deslocar o nascedouro da governamentalidade moderna para muito antes do momento em que Foucault o havia assinalado, isto é, o século XVIII e a emergência do modelo liberal. De acordo com o pensador italiano, o arcano do poder moderno seria identificável no "árido latim dos tratados medievais e barrocos sobre o governo divino do mundo" (2011, p. 11). Ou seja, em um plano eminentemente teológico, em princípio bastante distante daquele, político, no qual os conceitos de governo e economia, bem como suas práticas correlatas, hoje se efetuam.

Em consonância com Schmitt, Agamben não compreende a secularização como o esvaecimento do aspecto religioso na Modernidade sob a forma de um "desencantamento do mundo" weberiano, mas prefere conceituá-la como uma forma de deslocamento contextual que mantém intactas as forças operantes, que se restringem a deslocar-se de um lugar para outro. É desta maneira que o autor já compreende o conceito em Profanaçôes, onde escreve:

[...] a secularização é uma forma de remoção que mantém intactas as forças, que se restringe a deslocar de um lugar a outro. Assim, a secularização política de conceitos teológicos limita-se a transmutar a monarquia celeste em monarquia terrena, deixando, porém, intacto o seu poder (Agamben, 2007b, p. 68).

Simon Critchley (2012), em sintonia com Agamben, defende que a secularização nada mais seria que a trajetória histórica de "metamorfoses da sacralização", o que implica reconhecer que, se há um modelo de soberania que se translada do âmbito teológico para o âmbito político, mantém-se intacta, para todos os efeitos, a articulação estrutural que alimenta a soberania, seja num contexto ou no outro. Seria desta maneira "secularizada", portanto, que a governamentalidade moderna possuiria a assinatura teológica do governo divino medieval. Tanto num âmbito quanto no outro, o poder é pensado desde uma dupla articulação: de um lado, o aspecto glorioso, separado, imutável da soberania; de outro, seu aspecto prático, imiscuido no mundo, sob a forma de um governo "brando e sutil" de coisas e pessoas,

Debates do NER, Porto Alegre, ANo I4, N. 24, P. I4I-I64, JUl./DeZ. 2013 
"como se estas governassem a si mesmas". O que une um polo a outro, nas palavras de Agamben, é uma espécie de "máquina bipolar da soberania", pela qual o segundo polo, em nome do primeiro, exerceria a governamentalidade.

Essa estrutura vicarial do poder é exemplificada, no campo teológico, pelas oposições entre providência geral (ordenatio) e providência especial (executio), no governo do mundo; Pai e Filho, na economia trinitária; discurso teológico (o que Deus é) e discurso econômico (como Deus age) no pensamento patrístico; entre outros exemplos. Já no campo político moderno, a oposição se atualizaria entre: Estado e governo; rei e ministro; lei e polícia; poder constituinte e poder constituído. A fórmula que melhor resume seu argumento nesta primeira parte do livro é:

O que nossa investigação mostrou é que o verdadeiro problema, o arcano central da política, não é a soberania, mas o governo, não é Deus, mas o anjo, não é o rei, mas o ministro, não é a lei, mas a polícia - ou seja, a máquina governamental que eles formam e mantêm em movimento (Agamben, 2011, p. 299).

De maneira bastante esclarecedora, Agamben revela também que a comunidade instaurada pelo cristianismo definiu-se, desde o apóstolo Paulo, nos termos de uma oikonomia e não de uma política. Evocando a paradigmática cisão econômico-política proposta por Hannah Arendt (2003), o filósofo nos recorda que o mesmo não ocorria no contexto clássico, onde o âmbito doméstico (oikonômico) e o âmbito público (político) permaneciam dissociados. A principal diferença entre um e outro se radicaria no fato de o primeiro ser pensado em termos monárquicos. Isto é, como defende São Jerônimo, citado por Benveniste, in navi, unus gubernator, in domo unus dominus. ["no navio, um só capitão; em casa, um só senhor"] (Benveniste, 1995, p. 297). Já o segundo âmbito seria pensado como um arranjo entre diversas potestades, todas elas de igual valor. Desta maneira, compreende-se por que uma das mais severas críticas de Aristóteles à república platônica (Pol., 1261a) se baseia no perigo de a polis tornar-se uma gigantesca oikia: o espaço de domínio de apenas um só, no qual todos os demais seriam antes administrados, de acordo com uma oikonomia doméstica, do que copartícipes, em uma comunidade política.

Debates do NER, Porto Alegre, ANo I4, N. 24, P. I4I-I64, JUl./DEZ. 2013 
Com o aparecimento do cristianismo, surge uma importação do termo "economia" para o plano teológico. Lê-se do apóstolo Paulo: "evangelizar para mim não é glória, senão necessidade (...) se o faço por imposição, é como um cargo de administração que me foi confiado" (1Cor 9, 16-17). É interessante notar que o apóstolo não se refere somente à sua atividade como imbuída de certa economia, mas também aos membros da comunidade messiânica com termos que pertencem ao vocabulário do gerenciamento doméstico: diakonos (criado), oikonomos (administrador), doulos (escravo). O próprio Cristo é referido como dono do oikos (dominus, em latim), e nunca com termos importados da política (anax, archōn) (Agamben, 2011, p. 38).

Para Agamben, essa autocompreensão da comunidade cristã nos termos de uma oikonomia, e não de uma política, teria tido consequências determinantes para a configuração posterior da soberania política, cada vez mais pensada em termos unitários. Primeiro em termos de monarquia pessoal (na figura dos reis medievais) e depois em termos de monarquia institucional (através do Estado como sujeito único e exclusivo da legitimidade política na Modernidade). Tanto as monarquias pessoais quanto as monarquias institucionais podem ser consideradas análogos terrenos da figura teológica da ordenatio, isto é, do polo inativo e separado da máquina bipolar que legitima, desde cima, a "governamentalidade". Mas o que dizer da governamentalidade em si? Em outras palavras, o que dizer do polo ativo, imiscuído no mundo (a executio) desta mesma máquina?

Ora, a teologia justificava certo "governo do mundo" devido ao fato de este, por obra do pecado original, ter se desviado e degenerado. Assim, o que movia a teologia econômica era um determinado sentido escatológico: a salvação do mundo, a construção do Reino, no final dos tempos. A governamentalidade, portanto, insere-se em um projeto temporal. Ela dura do início até o fim do mundo, quando, por acabada a obra, também cessa a atividade governamental. $\mathrm{Na}$ teologia, este momento coincide com o esgotamento da atividade salvífica dos santos e dos anjos, que passam a tão somente louvar a

4 Oikonomian pepisteumai, literalmente "fui investido fiduciariamente de uma oikonomia”, de acordo com Agamben (2011, p. 36).

Debates do NER, Porto Alegre, ANo I4, N. 24, P. I4I-I64, JUl./DEZ. 2013 
glória do Senhor, que se confunde com sua inoperosidade. O final da história é a pura quietude, o cessamento de toda a atividade governamental. Para o autor,

[...] o paradigma cristão do governo, assim como a visão da história que lhe é solidária, dura da criação ao fim do mundo. A concepção moderna da história, que retoma em muitos aspectos - sem se dar plenamente conta do que ela implica - o modelo teológico, encontra-se, por isso mesmo, em uma situação contraditória. De um lado, abole a escatologia e prolonga ao infinito a história e o governo do mundo; de outro, vê reflorescer incessantemente o caráter finito do próprio paradigma (Agamben, 2011, p. 181).

Se a governamentalidade é uma "arte de administrar pessoas e coisas", poderíamos argumentar que sua assinatura teológica também a faz ser uma arte de administrar pessoas e coisas de acordo com um projeto, de acordo com um fim. Ela é, portanto, teleológica. Percebe-se por que não há templos na Nova Jerusalém descrita no livro do Apocalipse: eles já não são mais necessários. Secularizando-se esta lógica, entende-se também por que não haveria Estado na sociedade comunista idealizada por Marx: cumprida a tarefa da Ditadura do Proletariado, ele não seria mais necessário. Tampouco o liberalismo, em suas versóes antigas e modernas, ver-se-ia livre desta assinatura: como compreender de outra maneira uma ideologia que prega a existência do Estado somente para "cumprir o estritamente necessário", até sua própria aniquilação em puro laissez-faire?

A escatologia, dessa forma, enquadra o curso da história e o captura através de uma governamentalidade. É dado um sentido à história, que se realiza como o cumprimento de uma tarefa. Em sua dimensão soteriológica, salvífica, o governo do mundo tem como objetivo, paradoxalmente, sua própria dissolução. Ou melhor, tem como objetivo a construção de uma realidade tal em que sua própria ação "governamental" não se torne mais necessária, pois o governo nada mais é que "o breve intervalo entre as duas figuras eternas e gloriosas do Reino” (Agamben, 2011, p. 180).

De acordo com Agamben, contudo, o princípio segundo o qual o governo do mundo se encerra no momento do Juízo Final possui uma única e importante exceção na teologia cristã: o inferno. Após a consumação dos 
séculos, se os anjos abandonam seus ministérios e hierarquias para glorificar a quietude do Reino, os demônios permanecem aplicando eternamente suas penas sobre os ímpios e os condenados. "O inferno é, assim, o lugar onde o governo do mundo sobrevive para sempre, ainda que de forma puramente penitenciária” (Agamben, 2011, p. 182).

Partindo desse ponto de vista, Agamben argumenta que o paradigma da política moderna, por sua impossibilidade de realização escatológica, é rigorosamente infernal. As escatologias políticas secularizadas fracassam uma atrás da outra, restando como possibilidade ou a perenização do governo (alternativa que se aproxima do inferno, esse governo infinito), ou o advento sempre renovado de novas promessas de salvação, promessas estas que irrompem na tessitura da história em momentos ímpares de violência criadora de direito, como as revoluções. Estes momentos de ruptura, no entanto, demonstram-se quase sempre demasiado fugazes, e logo são capturados pela máquina governamental.

Espaços de reclusão como Guantánamo e Abu Ghraib definiriam o contexto presente. Seus prisioneiros seriam como protótipos daquilo que, sendo administrado de uma determinada forma, apresenta-se como puro objeto de governo e administração para o poder soberano, em um contexto no qual ele é o único sujeito do poder. É neste exato ponto da política contemporânea como uma espécie de inferno penitenciário que $O$ Reino e a Glória remete o leitor de volta ao círculo agambeano de interpretação da governamentalidade moderna, evocando as conclusões precedentes de Homo Sacer e Estado de Exceção.

Ora, como vimos anteriormente, o espaço onde só há um sujeito de poder é um espaço que podemos classificar como doméstico, no qual se realiza antes uma economia do que uma política. No decurso das metamorfoses da sacralização, a divindade econômica da teologia cristã fora substituída pelas figuras modernas do Estado e do Mercado, que passaram a administrar domesticamente, economicamente, os espaços compartilhados da ação humana. E se isto é fruto de uma determinada "secularização", Agamben indica que se torna possível combatê-la - ou ao menos desativá-la - desde uma determinada "profanação". Passo agora a analisar os sentidos dados

Debates do NER, Porto Alegre, ANo I4, N. 24, P. I4I-I64, JUl./DeZ. 2013 
pelo autor a este conceito, evocando suas formulações no último ensaio do volume Profanaçôes e na segunda metade de O Reino e a Glória, dedicada à arqueologia das formas de aclamação.

\section{OS SENTIDOS DA PROFANAÇÃO}

Para Agamben, o que alimenta a máquina bipolar da soberania seria uma espécie de "economia da glória". Esta, assim como a estrutura teológicogovernamental do poder, também teria se secularizado, sob a forma das modernas modalidades de aclamação e formação de consensos, como a opinião pública midiatizada, a publicidade e o consumo de massas. Estas modalidades de aclamação seriam importantes para o funcionamento da máquina bipolar por "animarem" o seu mecanismo interno, assim como as aclamações religiosas, em determinado sentido, também tinham sua função na economia teológica da salvação.

Agamben reconstrói a trajetória da glorificação e da aclamação desde as cerimônias públicas romanas até sua absorção pela Igreja Católica e sua liturgia, passando pelo culto imperial bizantino e por uma detida análise sobre os cânticos de aclamação dos missais medievais. De acordo com o autor, o termo "liturgia", derivado de laos ("povo"), significaria etimologicamente "prestação pública", e a Igreja sempre teria insistido "em sublinhar o caráter público do culto litúrgico, em oposição às devoçôes privadas" (Agamben, 2011, p. 193). O que reuniria os âmbitos da glória e do reino, portanto, seria a íntima vinculação existente entre liturgia e oikonomia, "pois tanto nos cantos e nas aclamaçôes de louvor quanto nos atos cumpridos pelo sacerdote é sempre e unicamente 'a economia do Salvador [oikonomia tou Sōtēros] que é significada” (idem, ibidem).

Agamben também relembra o papel exercido pelo protestantismo como vetor de circunscrição da religião aos limites da privacidade e da moralidade no ocidente moderno (circunscrição esta que atinge em Kant, através de sua obra A religião nos limites estritos da razão (1793 [2006]), seu ponto culminante). Além do resgate da obra de Peterson, portanto, o que ocorre aqui é uma referência explícita à investigação de Hans Urs von Balthasar denominada

Debates do NER, Porto Alegre, ANo I4, N. 24, P. I4I-I64, JUl./DEZ. 2013 
Herrlichkeit: eine theologische Aesthetik, obra na qual se dedica a desenvolver a teologia cristã à luz do terceiro transcendental, o "belo". De acordo com von Balthasar, os dois primeiros transcendentais (o "verdadeiro" e o "bom”) já teriam sido suficientemente analisados e desenvolvidos pela teologia canônica, de modo que o "belo" ainda permaneceria como o transcendental esquecido da teologia cristã. Segundo Agamben, o autor escreve a obra contra o protestantismo, por este ter "desestetizado a teologia" (2011, p. 217).

Purgada a religiosidade de seus aspectos conspícuos e ostentatórios, as modalidades de legitimação da soberania através da aclamação pública acabam sendo transpostas para o âmbito secular, o que dá origem aos fenômenos modernos de "religiosidade civil" emblematicamente analisados por Catroga (2006) e outros autores. Figuras como o "altar da pátria" reproduziriam, no âmbito estatal e profano, a mesma economia da glória que animara a Igreja em outros séculos. Para Agamben, esta glorificação permaneceria ativa nas democracias liberais. Por trás da teoria de legitimação do poder através do sufrágio individual, universal e secreto, operaria uma verdadeira máquina de produção de consensos e aclamação glorificante, assentada agora nos mecanismos de produção e disseminação da opinião pública, como o entretenimento e a publicidade. Esta é uma opinião pública que se distancia do modelo hegeliano, para o qual sua emergência se constitui como momento lógico da realização histórica da liberdade. Igualmente, o autor oferece objeções bastante sérias aos teóricos do agir comunicativo, como Jurgen Habermas:

A democracia contemporânea é uma democracia inteiramente fundada na glória, ou seja, na eficácia da aclamação, multiplicada e disseminada pela mídia além do que se possa imaginar (que o termo grego para glória - doxa - seja o mesmo que designa hoje a opinião pública é, desse ponto de vista, mais do que mera coincidência). E, como já havia ocorrido nas liturgias profanas e eclesiásticas, esse suposto "fenômeno democrático originário" é mais uma vez capturado, orientado e manipulado nas formas e segundo as estratégias do poder espetacular. (...) Começamos assim a compreender melhor o sentido das atuais definições da democracia como government by consent ou consensus democracy, e a decisiva transformação das instituições democráticas que está em questão (Agamben, 2011, p. 279).

Debates do NER, Porto Alegre, ANo I4, N. 24, P. I4I-I64, JUl./Dez. 2013 
Dessa maneira, para Agamben, os teóricos democráticos e laicos do agir comunicativo correriam o paradoxal risco de se aproximarem, ao fim e ao cabo, das elegias conservadoras e antiliberais da aclamação produzidas no começo do século XX, notadamente por Schmitt e Peterson. A proposição de um novo modelo político, nesse sentido, deve partir de algo que não possa ser capturado pela economia da glória e pelo paradigma gerencial. Ela deve partir da desativação deste mesmo modelo, donde a pertinência da profanação.

A profanação implicaria uma neutralização daquilo que profana. Assim, de acordo com o autor, depois de ter sido profanado, aquilo que estava indisponível e separado - sacralizado - perde sua aura e acaba sendo restituído ao uso comum. Em suas palavras, a profanação "desativa os dispositivos de poder e devolve ao uso comum os espaços que ele havia confiscado" (2007b, p. 68). A metáfora empregada por Agamben é a da criança que brinca com objetos sacros ou de trabalho sem, com isso, estar cumprindo ofícios religiosos ou econômicos. No jogo da criança, a potencialidade de um emprego religioso ou econômico para os objetos não é de modo algum anulada, mas, graças a ele, o objeto é aberto a um novo e possível uso. $\mathrm{O}$ que parece estar em jogo, portanto, é a liberação de novas potências para o objeto em questão, ao desativar o imperativo sagrado que o obriga a certo decurso teleológico. Para Agamben,

A atividade que daí resulta torna-se dessa forma um puro meio, ou seja, uma prática que, embora conserve tenazmente a natureza do meio, se emancipou da sua relação com uma finalidade, esqueceu alegremente seu objetivo, podendo agora exibir-se como tal, como meio sem fim. Assim, a criação de um novo uso só é possível ao homem se ele desativar o velho uso, tornando-o inoperante (Agamben, 2011, p. 75).

Acima de tudo, a profanação é um dispositivo de anulação teleológica. E se a escatologia secularizada que conforma o paradigma econômico-gerencial é uma teleologia, logo se percebe de que maneira a profanação pode ser empunhada como ferramenta de combate a este paradigma. Pensando na atual crise financeira que grassa nos países do hemisfério norte, problema 
a respeito do qual Agamben tem consultado na esfera pública ${ }^{5}$, percebe-se de que maneira algo como uma profanação ao paradigma poderia vir à tona. Certa racionalidade "econômica" mais ou menos acordada entre os gestores tecnocráticos da crise impóe que as saídas para o colapso político, econômico e social da zona do Euro ou da dívida pública norte-americana oscilem entre um número reduzido de opções: aumentar ou não aumentar os impostos para os mais ricos, cortar ou não cortar gastos militares, salvar ou não salvar a moeda comum, permanecer ou não permanecer na zona de abrangência dela. $\mathrm{O}$ profanador perguntaria: mas será que só há estas opções? Devemos salvar o Euro a qualquer custo? Que alternativas haveria ao modelo em geral? De que outra maneira poderíamos organizar as forças sociais e produtivas, dentro de uma nova lógica?

Em certa medida, experiências como o Occupy Wall Street - que deu ao Parque Zucotti e às imediações da referida avenida em Nova York um novo uso, desprovido de qualquer finalidade econômica específica - poderiam ser consideradas uma espécie de profanação. Talvez próxima à ideia de parrésia $^{6}$, a profanação num contexto como o atual poderia se dar através de uma ousadia retórica na esfera pública, capaz de proferir perguntas conside-

5 Em uma entrevista concedida recentemente a um jornal italiano (Ragusa News, 16/08/2012), Agamben argumenta: "Para entendermos o que está acontecendo [na atual crise global], é preciso tomar ao pé da letra a ideia de Walter Benjamin, segundo o qual o capitalismo é, realmente, uma religiāo, e a mais feroz, implacável e irracional religião que jamais existiu, porque não conhece nem redenção nem trégua. Ela celebra um culto ininterrupto cuja liturgia é o trabalho e cujo objeto é o dinheiro. Deus não morreu, ele se tornou Dinheiro. O Banco - com os seus cinzentos funcionários e especialistas - assumiu o lugar da Igreja e dos seus padres e, governando o crédito (até mesmo o crédito dos Estados, que docilmente abdicaram de sua soberania), manipula e gere a fé - a escassa, incerta confiança - que o nosso tempo ainda traz consigo. Além disso, o fato de o capitalismo ser hoje uma religião, nada o mostra melhor do que o título de um grande jornal nacional [italiano] de alguns dias atrás: "salvar o euro a qualquer preço". Isso mesmo, "salvar" é um termo religioso, mas o que significa "a qualquer preço"? Até ao preço de "sacrificar" vidas humanas? Só numa perspectiva religiosa (ou melhor, pseudorreligiosa) podem ser feitas afirmaçōes tão evidentemente absurdas e desumanas". Disponível em português em: <http://www.ihu. unisinos.br/noticias/512966-giorgio-agamben>. Acesso em: 19 set. 2012.

6 Em retórica, a ousadia para falar com franqueza e convicção no espaço público.

Debates do NER, Porto Alegre, ANo I4, N. 24, P. I4I-I64, JUl./DeZ. 2013 
radas capciosas e heréticas em relação aos consensos políticos e econômicos vigentes, ou dar uso diferenciado a objetos e locais marcados por um mesmo e viciado emprego, sem temer o açoite divino prometido por Agostinho e Lutero para quem ousa fazer perguntas impertinentes.

A possibilidade de fazer estes questionamentos permitiria aos sujeitos viver sob o signo do "como se não", não muito diferente do hōs mē que, na teologia paulina, indica a clivagem entre a vida que vivemos e a vida para que e em que vivemos (Agamben, 2011, p. 271; Critchley, 2012). Exatamente a partir deste ponto é possível pensar a ponte que liga a profanação, como dispositivo que desativa o paradigma, e o messianismo, como alternativa esboçada por Agamben contra a escatologia secularizada.

\section{OS SENTIDOS DO MESSIÂNICO}

De acordo com Bolton,

Puede ser instructivo abordar la diferencia que, según Agamben, existiria entre mesianismo y escatología. En efecto, para el filósofo italiano, la modernidad habría igualado estas dos categorias, con lo cual, habría hecho imposible advertir lo esencial del mesianismo paulino, a saber, que este se define como una suspensión del tiempo en el tiempo. Si la escatología sitúa a lo por venir al "final del tiempo" el mesianismo, por su parte, ló inscribe en el "ahora" porque este no es el final del tiempo, sino, a la inversa, "el tiempo del final" (Bolton, 2010, p. 315).

Parece claro em que sentido a escatologia se projeta como um "final do tempo" nos termos em que Agamben a descreve em O Reino e a Glória. Mas o que significaria este "tempo do final" que caracterizaria o messiânico? Ainda que Agamben tenha tratado do tema em obras anteriores, como The time that remains (2005) e $A$ comunidade que vem (1993), a dimensão messiânica retorna no final de $O$ Reino e a Glória como uma espécie de consequência da "arqueologia da glória" orquestrada na segunda metade do livro, pois é no próprio conteúdo do messianismo que Agamben encontra resposta à fulcral pergunta: por que o poder necessita da inoperosidade e da glória, encenadas nas liturgias antigas e modernas, religiosas e secularizadas?

Debates do NER, Porto Alegre, ANo I4, N. 24, P. I4I-I64, JUl./DEZ. 2013 
Ora, como bem expressa o autor em The time that remains (2005), a instância messiânica "emerge no tempo histórico e torna a lei mosaica inoperante” (p. 122). Em um determinado sentido, o compromisso da nova aliança, instaurada pelo Messias, é aquele que suplanta a velha ordem, que a torna inoperante. E a inoperância, como vimos, é uma das marcas do Reino, cuja conquista a escatologia governamental submete à realização de um projeto histórico, temporal. Aquele que vive no Messias, em contrapartida, experiencia esta inoperosidade desde já, vivendo hōs $m \bar{e}$, "como se não".

Referindo-se à teologia paulina, Agamben (2011) relembra que a relação entre a vinda do Messias e a lei é descrita pelo apóstolo através do verbo katargein - tornar inoperante. De certa maneira, viver messianicamente significa tornar inoperante a vida que estamos vivendo, as leis sob as quais estamos vivendo. Próximo ao argumento esboçado por Benjamin (1989) em um ensaio publicado após a I Guerra Mundial, denominado Crítica da Violência, Agamben enxerga o messiânico como uma forma de vida que aniquila, torna inoperoso, o direito vigente. Neste pequeno texto, Benjamin argumenta a respeito de uma "violência divina" [göttliche Gewalt], a única capaz de aniquilar a "violência mítica" [mytische Gewalt] que configura o direito secular:

Se a violência mítica é instauradora de direito, a divina é aniquiladora; se aquela coloca limites, esta os aniquila; se a mítica é simultaneamente culpabilizadora e expiatória, a divina é libertadora; se aquela é ameaçadora, esta é impressionante; se aquela é sangrenta, esta é letal de maneira não sangrenta [aufunblutige Weise letal] (Benjamin, 1989, p. 199).

A violência divina cumpre sua letalidade sem ser sangrenta: forma alternativa de dizer que ela é inoperante, isto é, não se atualiza num movimento temporal que conjuga meios e fins. No máximo, trata-se de um tipo bastante específico de operosidade, em que potência e ato coincidem, como no Reino descrito pelos teólogos. A vida que vivemos, obviamente, é aquela que se projeta como tessitura da história presente, ligada ao cumprimento de uma tarefa, uma finalidade, um sentido determinado e inexorável. Vivemos na operosidade. $\mathrm{O}$ messianismo nos abre a possibilidade de desativá-la. $\mathrm{O}$ cerne da mensagem messiânica de rejeição deste mundo se depreende de 1 $\operatorname{Cor} 7,29-32$, onde se lê:

Debates do NER, Porto Alegre, ANo I4, N. 24, P. I4I-I64, JUl./DEZ. 2013 
Digo-vos, pois, irmãos: o tempo é curto. Só resta que os que têm mulher vivam como se [hōs $m \bar{e}$ ] não a tivessem; os que choram, como se não chorassem; os que se alegram, como se não se alegrassem; os que compram, como se não possuíssem; e os que usam deste mundo, como se dele não usassem; porque passa a aparência deste mundo.

Para o pensador, a transformação do messiânico em escatológico teria sido o grande legado dos teólogos formuladores do paradigma econômicogerencial no alvorecer da tradição cristã. Com eles, o messiânico fora deslocado para os finais; fora subtraído da temporalidade presente, e se realiza como expectativa futura de vida gloriosa. O Messias torna-se aquele que cumpre a lei, e não mais a desativa. A oposição enfocada por Agamben (2005) é aquela entre nomos e pistis: enquanto a primeira [nomos, lei] encapsula o excesso de significado e a novidade da mensagem cristã em um conteúdo a ser cumprido, a segunda [pistis, fé] mantém a mensagem aberta e inapreensível por qualquer determinação ${ }^{7}$.

"Qualquer improfanável", argumenta Agamben (2007b, p. 279), "baseia-se no aprisionamento e na distração de uma intenção autenticamente profanatória". Apostando nesta distração aprisionante, os formuladores da doutrina econômica teriam substituído o que em Paulo era "genérico e indeterminado" (Agamben, 2011, p. 271) pela realização histórica de um conteúdo, de uma substância - uma teleologia, portanto. Substituindo-se a "salvação" pela "liberdade" como conteúdo a ser realizado pela história, tem-se a secularização do paradigma providencial no hegelianismo e, através dele, em todas as demais escatologias modernas. Todas as potências, todas as virtualidades, são remetidas à pressão da necessidade teleológica, demandando, para sua libertação, uma urgente profanação.

De acordo com o raciocínio de Agamben, a inoperosidade seria possível de ser alcançada desde já, libertando as potências do jugo escatológico que

7 “A Igreja, depois dos dois primeiros séculos de esperança e expectativa, já tinha concebido sua função com o objetivo essencial de neutralizar a nova experiência da palavra que Paulo, ao colocá-la no centro do anúncio messiânico, havia denominado pistis, fé" (Agamben, 2007b, p. 76).

Debates do NER, Porto Alegre, ANo I4, N. 24, P. I4I-I64, JUl./DEZ. 2013 
as escraviza em prol de um fim específico. Para reintroduzir sentido na política, portanto, seria preciso passar primeiro pela desativação de qualquer projeto acabado e bem-determinado para ela, na medida em que "o ser que vem é o ser qualquer" (Agamben, 1993, p. 11). Por "qualquer", o pensador compreende o ser indeterminado, que não pode ser definido por um conteúdo específico. Como bem sintetiza Milovic (2009, p. 112), o messianismo é "algo que talvez se realize", de modo que "o sentido da política não pode ser a reificação da ação dentro de um mundo dominado pela teleologia" (idem, ibidem), pela inexorabilidade. $\mathrm{O}$ messianismo significa a permanente abertura; um horizonte político que jamais se reifica; a preservação da potência em seu direito de não se realizar, de não se consumir inexoravelmente em ato.

\section{CONSIDERAÇÕES FINAIS}

A posição de Agamben pode ser criticada a partir de vários flancos. Em um primeiro nível, poderia se argumentar que o autor não consegue se desvencilhar de um lastro teológico, substituindo aquele que lhe parece conivente com as formas perversas de poder moderno (a escatologia) por aquele que the parece restaurar o sentido originário da comunidade política (o messianismo). Ademais, conforme a crítica de Negri (2008), suas proposições políticas não parecem atingir o cerne do modelo capitalista avançado que critica, pois mantém intacto (e pouco disserta sobre) seu verdadeiro e mais potente "improfanável": a propriedade privada e as relações concretas de produção.

Milovic vai mais longe e salienta: "talvez Agamben esvazie a política dos sujeitos concretos, aqui e agora” (2009, p. 112). Isto se daria pelo fato de que, desvinculada de qualquer teleologia e qualquer reificação, a política proposta por Agamben periga redundar em uma prática política vazia: em nome do que, afinal de contas, se luta? Qual o objetivo do engajamento na vida política? Quem age politicamente? A resposta a estas três perguntas demanda, invariavelmente, algum tipo de teleologia ou reificação, pois é difícil se pensar na ação política sem uma finalidade concreta (uma teleologia) ou sem a produção de identidades, definidas e objetivadas através do engajamento na ação política (uma reificação).

Debates do NER, Porto Alegre, ANo I4, N. 24, P. I4I-I64, JUl./DeZ. 2013 
Contudo, das objeçõos que podem ser feitas ao messianismo de Agamben, a questão de como proceder a uma "profanação" efetiva no contexto contemporâneo é uma das mais pertinentes de serem pensadas. O próprio autor reconhece esta dificuldade ao concordar com Benjamin (1991) que o capitalismo talvez seja a religião mais extrema que já existiu; religião voraz, expansiva e capturadora (Agamben, 2007b). Em permanente estado de culto, sob a forma de trabalho e consumo incessantes, o capitalismo como religião parece fornecer pouco espaço às atitudes profanatórias:

[...] se profanar significa restituir ao uso comum o que havia sido separado na esfera do sagrado, a religião capitalista, na sua fase extrema, está voltada para a criação de algo absolutamente Improfanável [...] o capitalismo não é senão um gigantesco dispositivo de captura dos meios puros, ou seja, dos comportamentos profanatórios (Agamben, 2007b, p. 71-76).

Mesmo assim, o autor acredita que ainda haja formas eficazes de profanação. Uma de suas apostas é na linguagem, "meio puro por excelência" (Agamben, 2007b, p. 76), epitomizada pela poesia. Para Agamben, a poesia é uma operação que torna inoperosa a língua, desativando todas as funções comunicativas e informativas capturadas pelo paradigma econômicogerencial ${ }^{8}$. A partir do poema, a língua "contempla sua potência de dizer e abre-se, dessa maneira, para um novo uso" (Agamben, 2011, p. 274). Nesse sentido, Agamben se vincula firmemente ao Heidegger tardio, conferindo ao poema uma centralidade filosófica essencial:

O que a poesia realiza em favor da potência de dizer, a política e a filosofia devem realizar em favor da potência do agir. Tornando inoperosas as operaçôes econômicas e biológicas, elas mostram o que pode o corpo humano, abrindo-o para um novo, possível uso (Agamben, 2011, p. 274).

8 "Os dispositivos midiáticos têm como objetivo, precisamente, neutralizar esse poder profanatório da linguagem como meio puro, impedir que o mesmo abra a possibilidade de um novo uso, uma nova experiência da palavra” (Agamben, 2007b, p. 76).

Debates do NER, Porto Alegre, ANo I4, N. 24, P. I4I-I64, JUl./DEZ. 2013 
À maneira de Badiou (1996), poder-se-ia alegar que esta perspectiva incorre em um deus ex machina poético, no qual o lirismo é convocado a salvar a filosofia das suas aporias e contradiçôes. Em defesa de Agamben, todavia, poderíamos pensar que, se há certas categorias políticas que temos dificuldade de questionar e problematizar radicalmente, talvez o que esteja na base desta dificuldade seja o caráter muitas vezes sacrossanto e inexorável com o qual estas categorias se apresentam nos discursos contemporâneos, o que denota a relevância da investigação de Agamben sobre o lastro teológico destas mesmas categorias. O próprio Negri (2008) reconhece que um dos principais méritos de $O$ Reino e a Glória é a demonstração do espírito religioso que anima a crença neoliberal contemporânea, espírito este que faz com que as querelas econômicas do presente se inflamem da mesma maneira que as querelas teológicas inflamavam os debatedores de antigamente.

Munido de suas "precauções arqueológicas" (Agamben, 2011, p. 281), o autor logra perceber na suposta inocuidade dos debates teológicos do passado um dos sentidos mais profundos do paradigma de poder vigente. E ao contrário das visões sobre a "secularização" como esgotamento do religioso na Modernidade, Agamben propõe um modelo alternativo, no qual ela representa, justamente, a mais pura realização e consumação do providencialismo teológico no tecido da história. Nesse sentido, talvez fosse interessante substituir os apelos liberais por um mundo cada vez mais "secularizado" pelo apelo agambeano a um mundo mais profanado, isto é, desativado de seu destino escatológico e restituído ao nosso uso e apropriação comuns. O secular, pelo secular, não desativa o paradigma econômico-governamental. Para que ele seja desativado, o autor roga que a "profanação do improfanável" (Agamben, 2007b, p. 79) seja tomada como a tarefa política da geração que vem. Como Negri (2008), ainda estamos à espera de delineamentos mais precisos do que seria esta ação política específica. 


\section{REFERÊNCIAS}

AGAMBEN, Giorgio. A comunidade que vem. Lisboa: Editorial Presença, 1993.

. Homo Sacer: o poder soberano e a vida nua I. Belo Horizonte: Editora da UFMG, 2002.

. The time that remains: a Commentary on the Letter to Romans. Stanford: Stanford University Press, 2005.

. The Power and the Glory. Conference at the $11^{\text {th }}$ Ganguli Memorial Lecture, CSDS, 11 jan. 2007a. Disponível em: <http://www.pubtheo.com/ page.asp?pid=1566>. Acesso em: 21 ago. 2012.

. Profanaçôes. São Paulo: Boitempo, 2007b.

. Estado de Exceção. São Paulo: Boitempo, 2007c.

O Reino e a Glória: uma genealogia teológica da economia e do governo. São Paulo: Boitempo, 2011.

ARENDT, Hannah. A Condição Humana. Rio de Janeiro: Forense Universitária, 2003.

ARISTÓTELES. The basic works of Aristotle [edited by Richard McKeon]. New York: Random House, 2001.

BADIOU, Alain. O ser e o evento. Rio de Janeiro: Zahar, 1996.

BAVARESCO, Agemir. A fenomenologia da opiniāo pública. São Paulo: Loyola, 2003.

BENJAMIN, Walter. Gesammelte Schriften, II, I. Frankfurt am Main: Suhrkamp, 1989.

. Gesammelte Schriften, IV. Frankfurt am Main: Suhrkamp, 1991.

BENVENISTE, Émile. O vocabulário das instituiçôes indo-européias (v. 1Economia, Parentesco, Sociedade). Campinas: Editora da UNICAMP, 1995. 
BERGER, Peter L. (Org.) The Desecularization of the World: resurgent religion and world politics. Grand Rapids: Erdmans, 1999.

BÍBLIA. Português. Bíblia Sagrada. Petrópolis: Vozes, Editora Santuário, 1982.

BOBBIO, Norberto. Dicionário de Política. v. 1. Brasília: Editora UnB, 1997.

BOLTON, Rodrigo Karmy. Soberanía y mesianismo: el gesto antikantiano en Giorgio Agamben. In: CASSIGOLI, Isabel; SOBARZO, Mario. Biopolíticas del Sur. Santiago de Chile: Editorial ARCIS, 2010.

BOURDIEU, Pierre. A Opinião Pública não existe. In: THIOLLENT, Michel. Crítica metodológica, investigação social e enquete operária. São Paulo: Polis, 1981. p. 137-151.

CASTRO, Edgardo. Qué es la política para la biopolítica? In: CASSIGOLI, Isabel; SOBARZO, Mario. Biopoliticas del sur. Santiago de Chile: Editorial ARCIS, 2010.

CATROGA, Fernando. Entre Deuses e Césares. Secularização, laicidade e religião civil: uma perspectiva histórica. Coimbra: Almedina, 2006.

CRITCHLEY, Simon. The faith of the faithless: experiments in Political Theology. New York/London: Verso, 2012.

FOUCAULT, Michel. Segurança, Território, População. São Paulo: Martins Fontes, 2008a.

O nascimento da biopolítica: curso dado no Collège de France (1978-1979). São Paulo: Martins Fontes, 2008b.

O governo de si e dos outros: curso no Collège de France (19821983). São Paulo: Martins Fontes, 2011.

FUKUYAMA, Francis. O fim da história e o último homem. Rio de Janeiro: Rocco, 1992.

Debates do NER, Porto Alegre, ANo I4, N. 24, P. I4I-I64, JUl./DeZ. 2013 
GÉREBY, György. Political Theology versus Theological Politics: Erik Peterson and Carl Schmitt. New German Critique 105, v. 35, n. 5, p. 7-33, 2008.

MILOVIC, Miroslav. Políticas do messianismo: algumas reflexões sobre Agamben e Derrida. In: Cadernos de Ética e Filosofia Política, v. 14, n. 1, p. 103-121, 2009.

NEGRI, Antonio. Sovereignity: that divine ministry of the affairs of earthly life. In: Journal of Cultural and Religious Theory, v. 9, n. 1, p. 96-100, 2008. SCHMITT, Carl. Teologia Política. Belo Horizonte: Del Rey, 2009.

WEBER, Max. A ética protestante e o "espirito" do capitalismo. São Paulo: Companhia das Letras, 2004. 